\title{
What explains the variation on the regenerative component dynamics of Araucaria
}

\section{Forests in southern Brazil?}

\author{
Manoela Bez Vefago`, Ana Carolina da Silva`, Tarik Cuchi®e, Guilherme Neto dos Santos ${ }^{\circledR}$, Amanda da Silva Nunes ${ }^{\circledR}$, Luiz Carlos

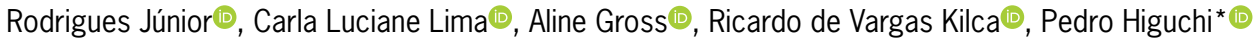

Universidade Estadual de Santa Catarina/Centro de Ciências Agroveterinárias - Depto. de Floresta, Av. Luiz de Camões, 2090 - 88520-000 - Lages, SC - Brasil.

*Corresponding author <higuchip@gmail.com>

Edited by: Rafael Rubilar Pons

Received August 28, 2017

Accepted May 16, 2018
ABSTRACT: The natural regeneration process is essential for forest maintenance since it is critical for establishing new tree individuals. This study aimed to improve the understanding of the regenerative component dynamics of Araucaria Forests in Southern Brazil. We investigated the effects of climate, light, tree component structure and anthropogenic disturbance on tree species regeneration. Regenerating communities from six different fragments in forest remnants of the "Planalto Sul Catarinense" region was evaluated in permanent plots two years after the first inventory. The following demographic rates were determined: recruitment, mortality, net change in the number of individuals and the changes to both upper and lower height classes. The following variables were measured in each fragment: altitude, climatic variables, light environment, tree component density and cattle presence. Association between dynamics rates, regenerating species abundance and explanatory variables was verified by the fourth-corner and RLQ methods. A total of 4,379 and 5,268 individuals were sampled for the first and second inventories, respectively, with recruitment rate $\left(21 \% \mathrm{yr}^{-1}\right)$ higher than mortality rate $\left(13 \% \mathrm{yr}^{-1}\right)$. The dynamics pattern of the fragment with greater presence of cattle stood out for the intense height increase of regenerating species caused by the presence of fast growth and light-demanding species. Natural regeneration of forest remnants under study is facing a structuring process. The main conclusions of this study were: i) climate and altitude play a relevant role in defining floristic identity and ii) chronic disturbances may influence the definition of ecological strategies.

Keywords: forest dynamics, cattle disturbance, climatic variables, mixed ombrophyllous forests

\section{Introduction}

The natural regeneration process is essential for forest maintenance, as it is critical for the establishment of new tree individuals. The understanding of regeneration dynamics allows inferences about the future development of the forest (Norden et al., 2009). This process depends on several factors beyond the intrinsic aspects of species, whose influence can be perceived in different spatial scales. At regional scale, there is evidence that climate defines the species regional pool with potential to be established as regenerating in a given location (Silva et al., 2017). At local scale, evidence lies in the availability of propagules, the amount of dispersers, the history of disturbance (Toriola et al., 1998), microclimatic conditions and environmental aspects.

Among the most important environmental variables, sunlight has been reported as relevant for establishing the regenerative component in forest understory due to its influence on tree growth (Whitmore, 1984, 1990; Brokaw, 1985; Denslow, 1987). Thus, species are traditionally classified in ecological groups according to their demands for light quality in early or late succession stages. Regarding limiting factors for the establishment of young individuals in understory, Stern et al. (2002) and Tobler et al. (2003) highlight the presence of cattle, which results in soil compaction and in increased mortality of seedlings due to herbivory and/or trampling of plants therefore changing vegetation richness and struc- ture, as already reported in some studies (e.g. Janicke, 2008; Smale et al., 2008).

Thus, a high heterogeneity of natural regeneration is expected on a regional scale due to climatic and environmental variations and the existence of different levels of fragmentation and degradation in forest ecosystems. The Araucaria Forest, mainly distributed in southern Brazil, is among the forests submitted to this kind of disturbance. Intensive logging and cattle ranching have threatened residual tree species populations. In this study, we aimed to improve our understanding of regeneration dynamics of the tree component in forest remnants in the "Planalto Sul Catarinense" region by analyzing influences of climatic conditions, environmental aspects (light), tree component structuring and anthropic actions on the natural regeneration process.

\section{Materials and Methods}

The study on dynamics was carried out in six fragments of an Araucaria Forest - one of them considered as a transition area between the Araucaria Forest and Deciduous Forest - in the municipalities of Lages, Urubici and Capão Alto, "Planalto Sul Catarinense" region. These fragments have been inventoried in previous studies (Table 1). We re-inventoried the fragments two years after the first research.

All forest remnants studied were subject to the same history of anthropic disturbance characterized by 
Table 1 - Characterization of the forest fragments inventoried in Araucaria Forest areas in southern Brazil.

\begin{tabular}{|c|c|c|c|c|c|c|}
\hline Municipality/Fragment & Geographical coordinates & Altitude $(m)^{*}$ & Sub-formation & $\mathrm{N}$ & Year 1 & Year 2 \\
\hline Lages/Aluvial & $27^{\circ} 51^{\prime} 03^{\prime \prime} \mathrm{S}$ and $0^{\circ} 13^{\prime} 31^{\prime \prime} 0$ & 936 & Alluvial & 48 & $2013^{a}$ & 2015 \\
\hline Urubici & $28^{\circ} 04^{\prime} 27^{\prime \prime} \mathrm{S}$ and $9^{\circ} 37^{\prime} 30^{\prime \prime} 0$ & 1514 & Upper-Montane & 25 & $2013^{b}$ & 2015 \\
\hline Capão Alto & $28^{\circ} 11^{\prime} 29^{\prime \prime} S$ and $50^{\circ} 45^{\prime} 34^{\prime \prime} 0$ & 845 & Araucaria-Deciduous Forests Transition & 30 & $2013^{c}$ & 2015 \\
\hline Lages/Pedras Brancas & $27^{\circ} 51^{\prime} 36^{\prime \prime} S$ and $50^{\circ} 11^{\prime} 35^{\prime \prime} 0$ & 989 & Montane & 50 & $2013^{d}$ & 2015 \\
\hline Lages/Epagri & $27^{\circ} 48^{\prime} 18^{\prime \prime} S$ and $50^{\circ} 19^{\prime} 59^{\prime \prime} 0$ & 963 & Montane & 25 & $2012^{e}$ & 2014 \\
\hline Lages/Parmanul & $27^{\circ} 47^{\prime} 04^{\prime \prime} S$ and $50^{\circ} 20^{\prime} 44^{\prime \prime} 0$ & 934 & Montane & 20 & $2012^{e}$ & 2014 \\
\hline
\end{tabular}

${ }^{*}$ Altitude extract from Worldclim (Hijmans et al., 2005). $\mathrm{N}$ = number of plots used to study the dynamics. aSilva et al., 2016; bDalla Rosa et al., 2016; 'Souza et al., 2017; 'Higuchi et al., 2015; ' Guidini et al., 2014.

intense logging in the 1950s, cattle presence and brushing in the understory. Cattle has free access to the forest in Urubici and Lages/Alluvial, making these areas the most anthropized ones. There are no reports of cattle occupation for the last ten years or so in the areas of the other plots.

Permanent plots were installed in variable numbers according to the characteristics of each of the six fragments and according to the sampling sufficiency obtained for each case. This imbalance did not affect the analysis of demographic rates, expressed in percentage. Natural regeneration dynamics was evaluated within the previously installed plots; only the tree individuals whose diameter at breast height, measured at $1.30 \mathrm{~m}$ from the ground (DBH) did not reach $5 \mathrm{~cm}$ were considered as part of the regenerative component.

In order to survey the regenerating individuals, each plot was subdivided into subplots varying in area according to plant size class: i) Class 1 - plants up to 1 $\mathrm{m}$ height, analyzed in $5 \mathrm{~m}^{2}$ subplots; ii) Class 2 - plants from 1 up to $3 \mathrm{~m}$ height, analyzed in $10 \mathrm{~m}^{2}$ subplots; and iii) Class 3 - plants higher than $3 \mathrm{~m}$ and DBH lower than $5 \mathrm{~cm}$, analyzed in $20 \mathrm{~m}^{2}$ subplots. Total area sampled can be obtained by multiplying the area sampled of each class by the number of plots sampled (Table 1). The minimum inclusion limit for Class 1 ranged from 10 to $20 \mathrm{~cm}$ according to the level of inclusion considered for the first inventory by the authors listed in Table 1 . We supposed that such small difference in minimum inclusion limit was not relevant to interpret the results. All regenerating tree individuals from the first inventory were identified with an aluminum tag and classified as class 1,2 or 3 . Identifications were possible by consulting experts and the angiosperms species were classified into families according to the APG IV system (Angiosperm Phylogeny Group, 2016).

All regenerating individuals from each plot were re-inventoried through the same methodology applied in the first inventory, considering the same size class criteria, in order to study their dynamics. Individuals that reached the minimum height of inclusion were taken as recruits, tagged, identified and measured. Surviving individuals were re-inventoried and classified in the new height classes, and dead individuals were registered.

All species were classified in their respective successional group by dividing them into pioneer and cli- max species according to the methodology proposed by Swaine and Whitmore (1988). According to OliveiraFilho et al. (2004), climax species were then subdivided into light-demanding climax, whose life cycle requires light to be completed, and shade-tolerant climax, which germinates as understory for its life cycle to be completed. Species classification relied on the existing literature and field observations.

Climatic variables and altitude of each of the fragments under study were obtained by the WorldClim database (Hijmans et al., 2005) (2.5 arc-min resolution): altitude (alt), annual mean temperature (bio1), mean diurnal range (bio2), isothermality (bio3), temperature seasonality (bio4), max temperature of warmest month (bio5), min temperature of coldest month (bio6), temperature annual range (bio7), mean temperature of wettest quarter (bio8), mean temperature of driest quarter (bio9), mean temperature of warmest quarter (bio10), mean temperature of coldest quarter (bio11), annual precipitation (bio12), precipitation of wettest month (bio13), precipitation of driest month (bio14), precipitation seasonality (bio15), precipitation of wettest quarter (bio16), precipitation of driest quarter (bio17), precipitation of warmest quarter (bio18) and precipitation of coldest quarter (bio19). Each area was categorized according to cattle presence or absence to create a variable related to such chronic disturbance, which is common in forest fragments from this region. Indirect readings of the leaf area index (LAI) were performed by using a LAI-2200 canopy analyzer for characterizing the light environment of each area. In 2016 Nov, 75 LAI readings were performed in each fragment therefore later obtaining a mean per area. In addition, information on the structure of the tree component of each fragment was obtained from the adult tree density values $(\mathrm{DBH} \geq 5$ $\mathrm{cm}$ ) of the forest inventories database of LABDENDRO/ UDESC (Laboratory of Dendrology at the State University of Santa Catarina, Brazil).

The demographic rates of the communities and populations of all areas were calculated. Algebraic models were used to obtain recruitment and mortality rates (Lieberman et al., 1985; Primack et al., 1985; Sheil and May, 1996): $\mathrm{MR}=\left(1-((\mathrm{No}-\mathrm{d}) / \mathrm{No})^{1 / t}\right) \times 100 ; \mathrm{RR}=(1-(1-\mathrm{r} /$ $\mathrm{Nt})^{1 / t} \mid \times 100$. Where: $\mathrm{MR}=$ annual mortality rate; $\mathrm{RR}=$ annual recruitment rate; $\mathrm{t}=$ time between inventories; $\mathrm{No}=$ initial tree number; $\mathrm{Nt}=$ final tree number after $\mathrm{t}$; 
$\mathrm{d}=$ number of dead trees and $\mathrm{r}=$ number of recruited trees. The number of individuals net change rate (CR) was also calculated through the Korning and Balslev equation (1994): $\mathrm{CR}=\left[(\mathrm{Nt} / \mathrm{No})^{1 / \mathrm{t}}-1\right] \times 100$. The formulas based on Sheil and May (1996) were applied for determining the size classes change rates: UP $=[1-(\mid$ No$\left.\left.\mathrm{NUC} / \mathrm{No})^{1 / \mathrm{t}}\right)\right] \times 100 ;$ Down $=\left[1-((\mathrm{No}-\mathrm{NLC}) / \mathrm{No})^{1 / \mathrm{t}}\right] \times 100$. Where: UP = rate of changes to upper height classes; Down $=$ rate of changes to lower height classes; NUC $=$ number of regenerating individuals that moved up to an upper height class; and NLC = number of regenerating individuals that moved down to a lower height class.

A multivariate approach combining the fourthcorner analysis and the RLQ methods was applied to verify the associations between the demographic rates, the distributions of abundances of regenerating species in the fragments and the explanatory variables (altitude, climate, light environment, adult tree component structure and disturbances caused by the presence of cattle) (Dray and Legendre, 2008; Dray et al., 2014). First, the multicollinear explanatory variables with Variance Inflation Factor (VIF) > 10 were removed. Then, three matrices were prepared: i) one with the explanatory variables of the areas under study $(\mathrm{R})$; ii) one with the relative abundances of the regenerating species from each area for species of high density (> 20 individuals) (L); and iii) one with the species demographic rates (Q). Only species with more than 20 individuals in the first inventory were considered to avoid the influence of expressive asymmetry in species representativeness on the demographic rates calculation, which is mainly caused by less abundant species. Since matrix L (species abundance) is dependent on sample intensity, a standardization of the sample effort based on the sample of 338 regenerating individuals related to the less abundant area was performed (PARNAMUL/Lages).

While the RLQ methods combine the three matrices through the correspondence analysis (CA) and the principal component analysis (PCA), allowing inferences about their co-structuring, the fourth-corner analysis verifies the statistical significance of such combinations (Dray et al., 2014). Two permutation tests ( $\mathrm{n}=49,999$ ) with models 2 (permutation of abundances among areas) and 4 (permutation of abundances among species) were sequentially applied for the fourth-corner analysis as proposed by Ter Braak et al. (2012). Furthermore, the significance values of the permutations were adjusted to multiple comparisons in agreement to Benjamini and Hochberg (1995). The analyses were carried out in the $\mathrm{R}$ statistical programming environment ( $\mathrm{R}$ version 3.4.1) with the vegan (Oksanen et al., 2017), usdm (Naimi, 2017), ade4 (Dray and Dufour, 2007) and raster (Hijmans, 2017) packages.

\section{Results}

The regenerative tree component increased $20 \%$ in the period analyzed (two years) from 4,379 individu- als in the first inventory to 5,268 in the second, as a result of a recruitment rate $\left(21 \% \mathrm{yr}^{-1}\right)$ expressively higher than the mortality rate $\left(13 \% \mathrm{yr}^{-1}\right)$ (Table 2$)$. Four individuals that were considered for the determination of rate of changes to upper height classes reached the adult class (dbh higher than $5 \mathrm{~cm}$ ) and are no longer counted as regenerating individuals. We also observed a $2 \% \mathrm{yr}^{-1}$ rate of changes to upper height classes and a $1 \% \mathrm{yr}^{-1}$ rate of changes to lower height classes.

Regarding taxonomic richness, there was a tendency to stability with little increase in species $13 \%$, from 121 to 124$)$, genera ( $3 \%$, going from 76 to 78 ) and botanical families ( $2 \%$, from 44 to 45 ). Of all sampled species, only three were identified at family and subfamily levels and four, at the gender level only. Moreover, ten individuals from year 1 and 25 individuals from year 2 were not identified due to leafless. The highest richness in both years was observed for the following families: Myrtaceae (28 and 31 species in the first and second inventories, respectively), Fabaceae (seven and nine), Lauraceae (six and five), Asteraceae (five in both years) and Solanaceae (five in both years).

The most abundant species were Nectandra megapotamica (Spreng.) Mez (213 and 320 individuals in the first and second inventories, respectively), Allophylus edulis (A.St.-Hil., Cambess. \& A.Juss.) Radlk. (235 and 275), Cupania vernalis Cambess. (199 and 233) and Matayba elaeagnoides Radlk. (186 and 213). Araucaria angustifolia (Bert.) Kuntze, characteristic species of the Araucaria Forest, did not appear among the ten most abundant understory species, showing 69 and 75 sampled individuals in the first and second years, respectively.

Most analyzed species (72 individuals) showed a positive net change. The highest recruitment rates among the most abundant species ( $>100$ individuals in at least one of the inventories) were observed for Calyptranthes concinna DC. $\left(34 \% \mathrm{yr}^{-1}\right)$ and Nectandra megapotamica $\left(32 \% \mathrm{yr}^{-1}\right)$, which also showed the highest net change values (69\% and $50 \%$, respectively). Symphyopappus itatiayensis (Hieron.) R.M.King \& H.Rob stood out with the highest mortality rate $\left(22 \% \mathrm{yr}^{-1}\right)$ and the highest rate of changes to upper height classes $\left(7 \% \mathrm{yr}^{-1}\right)$. Campomanesia xanthocarpa O.Berg showed the highest rate of changes to lower height classes $\left(4 \% \mathrm{yr}^{-1}\right)$. Although Annona rugulosa (Schltdl.) H.Rainer showed a higher recruitment than mortality rate, it had a negative net change due to losses of individuals, not caused by mortality but by their change to the adult component.

A high heterogeneity of the regenerative component dynamics was observed, mainly due to the interaction between the following variables: climatic, altitude, cattle presence (Figures $1 \mathrm{~A}$ and $\mathrm{C}$ ) and floristic-structural composition of remnants (Figures 1A, B and D). The first two axes of the RLQ ordination explained 99 $\%$ of the relation between the explanatory variables, demographic rates and floristic-structural composition of remnants; $82 \%$ of all variation was explained by the first axis. Indeed, the fourth-corner analysis indicated 
Table 2 - Number of individuals of the regenerating species sampled in the first (N1) and second (N2) inventory years, followed by their respective mortality rates (MR), recruitment (RR), change to upper class of height (UP), change to lower class of height (Down) and net change for the number of individuals (CR), ordered according to their successional group (P, L or S), for Araucaria Forest areas in southern Brazil.

\begin{tabular}{|c|c|c|c|c|c|c|c|}
\hline Species & N1 & N2 & MR & $\mathrm{RR}$ & UP & Down & $\mathrm{CR}$ \\
\hline \multicolumn{8}{|l|}{$\mathrm{P}$ (pioneer) } \\
\hline Acca sellowiana (0.Berg) Burret & 1 & 2 & 0 & 29.3 & 0 & 0 & 100 \\
\hline Baccharis dentata (Vell.) G.Barroso & 5 & 3 & 22.5 & 0 & 0 & 10.6 & -40 \\
\hline Berberis laurina Thunb. & 10 & 11 & 10.6 & 14.7 & 5.1 & 0 & 10 \\
\hline Celtis iguanaea (Jacq.) Sarg. & 22 & 28 & 14.7 & 24.4 & 2.3 & 2.3 & 27.3 \\
\hline Cestrum intermedium Sendtn. & 2 & 3 & 0 & 18.4 & 0 & 0 & 50 \\
\hline Clethra scabra Pers. & 7 & 7 & 7.4 & 7.4 & 0 & 0 & 0 \\
\hline Duranta vestita Cham. & 4 & 4 & 29.3 & 29.3 & 0 & 0 & 0 \\
\hline Escallonia bifida Link \& Otto & 1 & 2 & 0 & 29.3 & 0 & 0 & 100 \\
\hline Lithrea brasiliensis Marchand & 4 & 3 & 29.3 & 18.4 & 0 & 0 & -25 \\
\hline Miconia cinerascens Miq. & 12 & 19 & 8.7 & 27.5 & 8.7 & 4.3 & 58.3 \\
\hline Miconia hiemalis A.St.-Hil. \& Naudin ex Naudin & 5 & 6 & 36.8 & 42.3 & 0 & 0 & 20 \\
\hline Miconia petropolitana Cogn. & 1 & 1 & 0 & 0 & 0 & 0 & 0 \\
\hline Miconia ramboi Brade & 3 & 3 & 0 & 0 & 0 & 0 & 0 \\
\hline Mimosa scabrella Benth. & 1 & 1 & 100 & 100 & 0 & 0 & 0 \\
\hline Moquiniastrum polymorphum (Less.) G. Sancho & 10 & 8 & 16.3 & 6.5 & 0 & 0 & -20 \\
\hline Myrcia oblongata DC. & 3 & 7 & 0 & 34.5 & 0 & 0 & 133.3 \\
\hline Pinus taeda L. ${ }^{*}$ & 1 & 1 & 0 & 0 & 0 & 0 & 0 \\
\hline Sapium glandulosum (L.) Morong & 1 & 1 & 0 & 0 & 0 & 100 & 0 \\
\hline Schinus polygamus (Cav.) Cabrera & 2 & 2 & 0 & 0 & 29.3 & 0 & 0 \\
\hline Schinus terebinthifolius Raddi & 1 & 0 & 100 & - & 0 & 0 & -100 \\
\hline Solanum pseudoquina A. St.-Hill. & 8 & 6 & 13.4 & 0 & 13.4 & 6.5 & -25 \\
\hline Solanum sanctaecatharinae Dunal & 3 & 8 & 0 & 38.8 & 0 & 0 & 166.7 \\
\hline Symphyopappus itatiayensis (Hieron.) R.M.King \& H.Rob. & 130 & 147 & 22 & 26.7 & 6.8 & 1.2 & 13.1 \\
\hline \multicolumn{8}{|l|}{ L (light-demanding climax) } \\
\hline Allophylus edulis (A.St.-Hil. Cambess. \& A.Juss.) Radlk. & 235 & 275 & 15.7 & 22.1 & 1.5 & 0.2 & 17 \\
\hline Allophylus guaraniticus (A.St.-Hil.) Radlk. & 79 & 98 & 12.1 & 21.1 & 0.6 & 1.3 & 24.1 \\
\hline Annona neosalicifolia H.Rainer & 5 & 16 & 0 & 44.1 & 0 & 0 & 220 \\
\hline Annona rugulosa (Schltdl.) H.Rainer & 75 & 74 & 10.6 & 10.7 & 3.4 & 0.7 & -1.3 \\
\hline Araucaria angustifolia (Bert.) Kuntze & 69 & 75 & 14.9 & 19.2 & 3.7 & 0 & 8.7 \\
\hline Aspidosperma australe Müll.Arg. & 1 & 3 & 0 & 42.3 & 0 & 0 & 200 \\
\hline Banara tomentosa Clos & 147 & 177 & 9.3 & 17.7 & 4.5 & 1 & 20.4 \\
\hline Blepharocalyx salicifolius (Kunth) O.Berg & 120 & 149 & 12 & 21 & 2.1 & 1.3 & 24.2 \\
\hline Campomanesia xanthocarpa 0.Berg & 87 & 101 & 13.6 & 19.8 & 1.2 & 3.5 & 16.1 \\
\hline Cedrela fissilis Vell. & 2 & 1 & 29.3 & 0 & 0 & 0 & -50 \\
\hline Cinnamodendron dinisii Schwanke & 12 & 11 & 8.7 & 4.7 & 4.3 & 0 & -8.3 \\
\hline Cinnamomum amoenum (Nees) Kosterm. & 2 & 2 & 29.3 & 29.3 & 0 & 0 & 0 \\
\hline Citronella gongonha (Mart.) R.A.Howard & 1 & 2 & 0 & 29.3 & 0 & 0 & 100 \\
\hline Citronella paniculata (Mart.) Howard & 16 & 12 & 33.9 & 23.6 & 0 & 3.2 & -25 \\
\hline Coutarea hexandra (Jacq.) K. Schum. & 7 & 11 & 0 & 20.2 & 0 & 0 & 57.1 \\
\hline Cupania vernalis Cambess. & 199 & 233 & 13.8 & 20.3 & 1.8 & 0.8 & 17.1 \\
\hline Dalbergia frutescens (Vell.) Britton & 130 & 142 & 16.3 & 19.9 & 1.6 & 1.9 & 9.2 \\
\hline Daphnopsis racemosa Griseb. & 24 & 33 & 4.3 & 18.4 & 6.5 & 6.5 & 37.5 \\
\hline Dasyphyllum brasiliense (Spreng.) Cabrera & 17 & 18 & 16 & 18.4 & 0 & 0 & 5.9 \\
\hline Dasyphyllum spinescens (Less.) Cabrera & 14 & 23 & 19.8 & 37.4 & 7.4 & 0 & 64.3 \\
\hline Drimys angustifolia Miers & 88 & 98 & 14.7 & 19.2 & 4.1 & 2.9 & 11.4 \\
\hline Drimys brasiliensis Miers & 21 & 21 & 24.4 & 24.4 & 2.4 & 2.4 & 0 \\
\hline Erythroxylum deciduum A.St.-Hil. & 4 & 3 & 29.3 & 18.4 & 0 & 0 & -25 \\
\hline Eugenia pluriflora DC. & 52 & 46 & 14.5 & 9.1 & 1.9 & 1.9 & -11.5 \\
\hline Eugenia uniflora $\mathrm{L}$. & 106 & 113 & 9.9 & 12.8 & 2.4 & 1.4 & 6.6 \\
\hline Eugenia uruguayensis Cambess. & 6 & 9 & 18.4 & 33.3 & 0 & 0 & 50 \\
\hline Ilex microdonta Reissek & 24 & 25 & 20.9 & 22.5 & 2.1 & 0 & 4.2 \\
\hline
\end{tabular}


Table 2 - Continuation.

Ilex taubertiana Loes.

Ilex theezans Mart. ex Reissek

Inga virescens Benth.

Jacaranda puberula Cham.

Lafoensia vandelliana Cham. \& Schltdl.

Lamanonia ternata Vell.

Ligustrum lucidum W.T. Aiton*

Ligustrum sinense Lour. *

Luehea divaricata Mart. \& Zucc.

Machaerium paraguariense Hassl.

Matayba elaeagnoides Radlk.

Maytenus aquifolia Mart.

Maytenus boaria Molina

Muellera campestris (Mart. ex Benth.) M.J. Silva \& A.M.G. Azevedo

Myrceugenia euosma (0.Berg) D.Legrand

Myrceugenia glaucescens (Cambess.) D.Legrand \& Kausel

Myrceugenia miersiana (Gardner) D.Legrand \& Kausel

Myrceugenia myrcioides (Cambess.) 0. Berg

Myrceugenia oxysepala (Burret) D.Legrand \& Kausel

Myrceugenia pilotantha (Kiaersk.) Landrum

Myrceugenia regnelliana (0.Berg) D. Legrand \& Kausel

Myrcia guianensis (Aubl.) DC.

Myrcia hartwegiana (O.Berg) Kiaersk.

Myrcia laruotteana Cambess.

Myrcia palustris DC.

Myrcia splendens (Sw.) DC.

Myrcianthes gigantea (D. Legrand) D. Legrand

Myrcianthes pungens (O.Berg) D. Legrand

Myrocarpus frondosus Allemão

Myrrhinium atropurpureum Schott

Myrsine coriacea (Sw.) R.Br. ex Roem. \& Schult.

Myrsine lorentziana (Mez) Arechav

Myrsine umbellata Mart.

Nectandra lanceolata Nees

Nectandra megapotamica (Spreng.) Mez

Ocotea puberula (Rich.) Nees

Ocotea pulchella (Nees \& Mart.) Mez

Oreopanax fulvus Marchal

Parapiptadenia rigida (Benth.) Brenan

Picrasma crenata (Vell.) Engl.

Podocarpus lambertii Klotzsch ex Endl.

Prunus myrtifolia (L.) Urb.

Scutia buxifolia Reissek

Sebastiania brasiliensis Spreng.

Sebastiania commersoniana (Baill.) L.B. Sm. \& Downs

Styrax leprosus Hook. \& Arn.

Syagrus romanzoffiana (Cham.) Glassman

Symplocos tetrandra (Mart.) Miq.

Symplocos uniflora (Pohl) Benth.

Xylosma ciliatifolia (Clos) Eichler

Xylosma tweediana (Clos) Eichler

Zanthoxylum kleinii (R.S.Cowan) P.G.Waterman

Zanthoxylum rhoifolium Lam.

$S$ (shade-tolerant climax)

Brunfelsia cuneifolia J.A.Schmidt

2

$1 \quad 0 \quad 100$

$29 \quad 27 \quad 9$

$0 \quad 1$

51

10

$54 \quad 12.6$

$84-121-6.1$

14

0

8

186

3

(9)

26

29

50

31

3

3
62

62

54

4

33

$0 \quad 2$

3

$22 \quad 27$

$7 \quad 11$

$12 \quad 16$

96

18

$9 \quad 7$

25.5

\begin{tabular}{cc}
9 & - \\
& 5.7 \\
\hline .6 & 100 \\
\hline 0 & - \\
\hline 5 & 29.3 \\
1 & 21.8
\end{tabular}

$\begin{array}{lll}0 & -100\end{array}$

$\begin{array}{ll}1.7 & -6.9\end{array}$

$1 \quad 3 \quad 5.9$

$\begin{array}{lll}1 & 0 & -100 \\ 0 & 6.5 & 75\end{array}$

6

1

11.8

3

15.1

42.3

18.4

17.3

10.1

$$
9
$$

11.7

8.7

$$
15.8
$$

0

7.5

7.7

8.1

11.7

10.9

9.9

5.7

13.4

18.4

11.8

19

4

17.8

29.3

16.9

25.8

10.9

10.9
42.3

20.9

10.2

10.2
18.8

18.8
9.5

7.6

11.3

14.7

- 100

$\begin{array}{lllll}42.3 & 0 & 0 & 0 & -66.7\end{array}$

17.4

$7.4 \quad 26.1$

$\begin{array}{cc}7.4 & 26.1 \\ 0 & 13.4\end{array}$

25.5

$\begin{array}{llll}3.4 & 0 & 0 & 33.3\end{array}$

$\begin{array}{ccccc}0.5 & 8.7 & 5.7 & 0 & -33.3 \\ 8.7 & 16.3 & 8.7 & 2.8 & 11.1\end{array}$

25.5

15

$15.5 \quad 0$

0

$-22.2$

Continue 
Table 2 - Continuation.

\begin{tabular}{|c|c|c|c|c|c|c|c|}
\hline Calyptranthes concinna DC. & 83 & 140 & 13.6 & 33.5 & 1.8 & 2.4 & 68.7 \\
\hline Campomanesia rhombea O.Berg & 2 & 2 & 0 & 0 & 0 & 0 & 0 \\
\hline Casearia decandra Jacq. & 156 & 191 & 8.4 & 17.2 & 2.6 & 2.6 & 22.4 \\
\hline Dicksonia sellowiana Hook. & 22 & 11 & 29.3 & 0 & 0 & 0 & -50 \\
\hline Eugenia pyriformis Cambess. & 8 & 7 & 6.5 & 0 & 0 & 0 & -12.5 \\
\hline Ilex paraguariensis A. St.-Hil. & 13 & 9 & 32.1 & 18.4 & 8 & 3.9 & -30.8 \\
\hline Maytenus dasyclada Mart. & 54 & 56 & 11.8 & 13.4 & 0.9 & 0 & 3.7 \\
\hline Myrceugenia mesomischa (Burret) D. Legrand et Kausel & 32 & 39 & 9.9 & 18.4 & 3.2 & 0 & 21.9 \\
\hline Myrcia hatschbachii D.Legrand & 58 & 84 & 7.2 & 22.8 & 3.5 & 2.6 & 44.8 \\
\hline Myrciaria delicatula (DC.) O.Berg & 60 & 75 & 8.7 & 18.4 & 2.5 & 0.8 & 25 \\
\hline Pilocarpus pennatifolius Lem. & 10 & 24 & 0 & 35.5 & 0 & 0 & 140 \\
\hline Psychotria carthagenensis Jacq. & 14 & 14 & 0 & 0 & 0 & 0 & 0 \\
\hline Roupala montana Aubl. & 61 & 57 & 17 & 14.2 & 0 & 0.8 & -6.6 \\
\hline Rudgea parquioides (Cham.) Müll.Arg & 48 & 71 & 7.6 & 24 & 1 & 2.1 & 47.9 \\
\hline Schaefferia argentinensis Speg. & 10 & 13 & 16.3 & 26.6 & 0 & 0 & 30 \\
\hline Sloanea monosperma Vell. & 1 & 0 & 100 & - & 0 & 0 & -100 \\
\hline Strychnos brasiliensis (Spreng.) Mart. & 25 & 38 & 8.3 & 25.7 & 2 & 0 & 52 \\
\hline Trichilia elegans A. Juss. & 61 & 85 & 13.2 & 26.4 & 0 & 1.7 & 39.3 \\
\hline \multicolumn{8}{|l|}{ Unclassified } \\
\hline Eugenia sp. & 0 & 3 & - & 100 & - & - & - \\
\hline Lauraceae undetermined & 1 & 0 & 100 & - & 0 & 0 & -100 \\
\hline Machaerium sp. & 2 & 2 & 0 & 0 & 0 & 0 & 0 \\
\hline Mimosoideae undetermined & 0 & 2 & - & 100 & - & - & - \\
\hline Myrceugenia sp. & 0 & 1 & - & 100 & - & - & - \\
\hline Myrtaceae undetermined & 0 & 1 & - & 100 & - & - & - \\
\hline Undetermined & 10 & 25 & 55.3 & 71.7 & 0 & 0 & 150 \\
\hline Solanum sp. & 2 & 4 & 0 & 29.3 & 0 & 0 & 100 \\
\hline Total & 4379 & 5268 & 13.2 & 20.9 & 2.4 & 1.4 & 20.3 \\
\hline
\end{tabular}

a significant global relation between the variables analyzed $(p=0.02)$.

The variables with high correlation to the first RLQ axis, the most explanatory one, were altitude (alt, loading $=-0.58)$, mean temperature of driest quarter (bio9, loading $=0.51$ ), mean diurnal range (bio2, loading $=0.44$ ) and cattle presence or absence (cattl.0, loading $=0.32$ and cattl.1, loading $=-0.32$ ) (Figure 1A). Urubici stood out in the first RLQ axis for occupying the extreme left of the ordination (Figure 1B) with the highest altitude and the lowest values of mean temperature of driest quarter, mean diurnal range and cattle presence. Capão Alto appeared at the other extreme by showing antagonistic conditions. No great distinctions along the first axis was noted in the areas in Lages, which occupied regions close to the ordination center.

The rate of changes to upper height classes showed the highest correlation with the first RLQ axis (loading $=-0.91$ ) (Figure 1C). In this sense, the dynamics pattern of the regenerative component in Urubici stood out due to the increased height growth of individuals, mainly determined by the great participation of the pioneer species Symphyopappus itatiayensis (Figure 1D). Climax species stood out on the opposite side of the graph, in areas of cattle absence.

\section{Discussion}

The short-term dynamics (two years) of natural regeneration were characterized by structural instability, showing an increased number of individuals and a great number of species moving to upper height classes, as well as richness stability. The structuring process of the regenerative component may be understood as a characteristic of areas that have undergone previous disturbances (Machado and Oliveira-Filho, 2010). The region of the Araucaria Forest, currently protected by law, was intensively exploited in the past, especially from the 1950s to the 1970s, and subjected to chronic disturbances, such as selective exploitation, cattle grazing and farming (Vibrans et al., 2011).

High stability in the number of species may indicate that: i) floristic richness recovers more slowly than forest structure does (Liebsch et al., 2008) or ii) due to their history of disturbance, the areas were submitted to a biological homogenization process (Tabarelli et al., 2012) thus floristic climax is reached before structural climax. This last hypothesis is corroborated by the fact that the Araucaria Forest areas are highly impacted and floristically impoverished because of over-time anthropogenic impacts, as reported by Vibrans et al. (2011). 


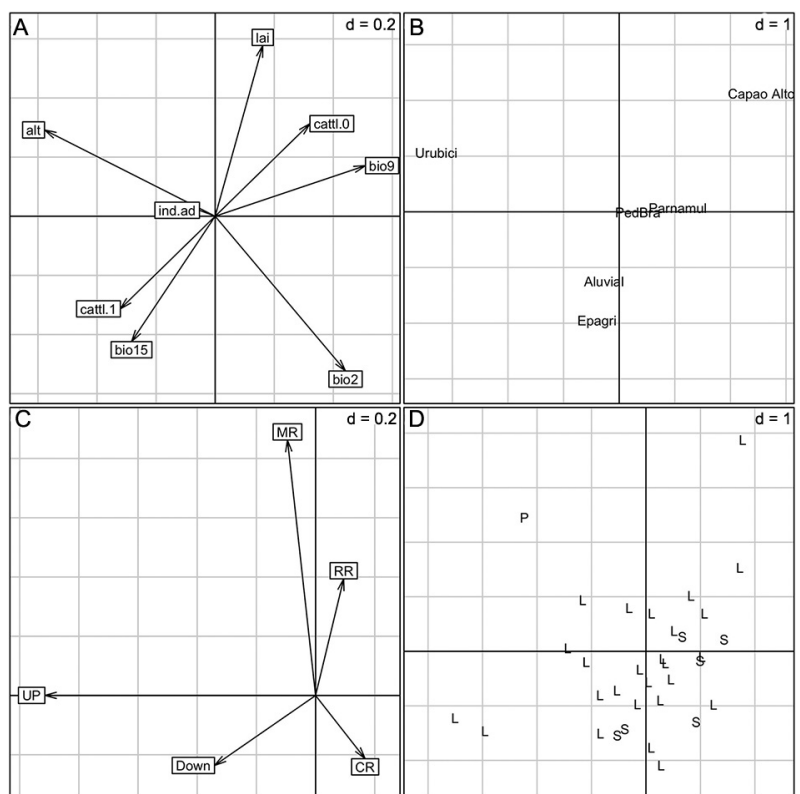

Figure 1 - Ordinations generated by the RLQ analysis for the regenerating communities from forest fragments in the "Planalto Sul Catarinense" region, indicating loadings of explanatory variables (A), with scores of forest remnants $(B)$, loadings of species demographic rates $(C)$ and scores of species indicated by their respective regeneration guilds (D). Letter $d$ at the top right corner indicates the scale grid dimension. alt = altitude; lai = leaf area index; cattl. 1 = cattle presence; cattl. 0 = cattle absence; bio2 $=$ mean diurnal range; bio9 $=$ mean temperature of driest quarter; bio15 = precipitation seasonality; ind.ad = tree adult component density $(\mathrm{dbh}>5 \mathrm{~cm})$; Urubici $=$ fragment analyzed in the municipality of Urubici; Capão Alto = fragment analyzed in the municipality of Capão Alto; PedBra, Parnamul, Epagri and Alluvial $=$ fragments analyzed in the municipality of Lages; MR = mortality rate; $\mathrm{RR}=$ recruitment rate; $\mathrm{CR}=$ net change rate in the number of individuals; UP = rate of changes to upper height classes; Down $=$ rate of changes to lower height classes; $P=$ pioneer species; $\mathrm{L}=$ light-demanding climax species; $\mathrm{S}=$ shade-tolerant climax species.

Among the species that comprise the understory regenerative component, Araucaria angustifolia showed low representativeness although it is the species that most characterizes the Araucaria Forest areas due to its dominance in the canopy. On the other hand, angiosperms (Nectandra megapotamica, Allophylus edulis, Cupania vernalis and Matayba elaeagnoides) composed the most expressive group. This confirms that $A$. angustifolia has low establishment capacity in understory conditions (Souza, 2007) when compared to species belonging to the Lauraceae and Sapindaceae families. As for angiosperms, the formation of a seedling bank in the understory is an important strategy for the regeneration of forest ecosystems.

The species demographic rates show that the angiosperms mentioned above had values of net change in number of individuals ( $>14 \% \mathrm{yr}^{-1}$ ) much higher (more than 1.8 times) to those observed for Araucaria angustifolia $\left(9 \% \mathrm{yr}^{-1}\right)$. However, despite its low representativeness in the understory, $A$. angustifolia manages to ensure viable regeneration over time, as highlighted by Paludo et al. (2011). Thus, its low representativeness in the understory results from its ecological features. As noted by Lusk et al. (2015), the pattern of demographic rates found in our study for angiosperms and gymnosperms in the understory is often observed in mixed forests worldwide. The authors suggested that the low density of gymnosperms as understory, in contrast to its high density in open areas, is related to its high tolerance to desiccation and frost in open areas when compared to angiosperms. In this sense, angiosperms show higher competitive efficiency in understory, where climatic conditions are less extreme, compared to gymnosperms, which, in turn, behave as colonizers of open areas.

Despite positive net change patterns and higher growth, several species, such as Campomanesia xanthocarpa, decreased to lower height classes as much as or even more than they moved to upper height classes. The reduced height of regenerating individuals can be explained by a variety of events, frequently of stochastic nature, which may be considered hostile to plant development, such as break due to mechanical damage (e.g. tree and branch fall, animals trampling, anthropic impact), herbivory and diseases. Slower-growing species, or those that remain suppressed under understory condition, are thus expected to be more susceptible to height reduction and, consequently, mortality (Inman-Narahari et al., 2014), due to longer exposure to these events. The results corroborate that young trees under understory condition are subject to a strong environmental pressure (Poorter, 2007), explaining why few individuals can reach the adult stage.

Symphyopappus itatiayensis is the only species among the most abundant (> 100 individuals) that can be classified as a typical pioneer, and had high mortality and height growth rates, which is common for species belonging to this functional group (Brokaw, 1987). Some studies have reported the positive relation between growth and mortality in forest ecosystems (Wright et al., 2010) and is understood as the result of a trade-off regarding the investment in attributes that maximize growth or survival thus defining different life strategies (Philipson et al., 2014).

$S$. itatiayensis occurred associated to the Urubici area, which also showed cattle presence, therefore suggesting that this type of chronic disturbance favors the establishment of species with this life strategy. Chronic disturbances in fragments of the Araucaria Forest hinders its successional advance, favoring pioneer species, as shown by Souza et al. (2012). On the other hand, cattle absence areas stood out by the presence of climatic species in the understory. This agrees with Vicente-Silva et al. (2016), who have analyzed successional gradients 
in the Araucaria Forest and highlighted that undisturbed areas at an advanced stage of succession are featured by an understory of species with functional attributes that characterize conservative strategies, typical of late species.

High density of $A$. angustifolia is expected in disturbed environments (Vibrans et al., 2011; Souza et al., 2012; Lusk et al., 2015) as it is also favored by a large canopy opening, according to its ecological characteristics. However, the Urubici area is a nebular forest, known for the low density of this species in this region. This may explain why $S$. itatiayensis replaced $A$. angustifolia as a colonizer in nebular forests of disturbed areas.

When analyzing the interrelation between species demographic rates, explanatory variables and floristicstructural organization of remnants, the regenerative component dynamics varied on regional scale, mainly because of the tree regenerating capacity of height growth. As mentioned, this occurred mainly due to the presence of species with high capacity of height growth in places under chronic disturbances, expressed by the presence of cattle in this case. This suggests that, although altitude (alt) and climatic aspects (bio2 and bio9) showed the highest explanatory power between variables in the RLQ analysis, chronic disturbances may play a decisive role in the pattern of natural regeneration dynamics on a regional scale. An experimental design with local replications is necessary to obtain more robust inferences about cattle influence, considering the fencing of areas to be compared with those one with free access by livestock. In this case, sub-formations could be considered as a random factor.

Thus, it can be inferred that altitude and climatic variables are determinant to define the set of species that can potentially occupy a given location in the spatial scale we considered, as Higuchi et al. (2012) already observed for the adult component of this phytophysiognomy. The expressive occurrence of $S$. itatiayensis rather than $A$. angustifolia in Urubici could be an example of this influence. Still, the role of chronic disturbances could be more relevant to define which ecological strategy prevails in the remnant, as proposed by Souza et al. (2012) and Lusk et al. (2015), here expressed by species demographic rates. Contrary to expectations, sunlight, characterized by LAI as well as the structuring of the tree component expressed by the density of adult individuals, did not influence the regional pattern of the regenerative component dynamics, suggesting that the variation of these variables, in relation to other explanatory variables, was not expressive enough to influence the demographic rates observed.

\section{Conclusion}

On regional scale, the short-term dynamics (two years) of the regenerative component was characterized by an increase in the number of individuals and stability of richness, which can be interpreted as a post-distur- bance recovery process. However, the species studied differed in their capacity to establish in the forest understory since the representativeness of angiosperms in the natural regeneration under understory condition was higher than Araucaria angustifolia.

In general, dynamics occurred in a spatial heterogeneous way and the highest variation occurred due to height growth of regenerating individuals. The influence of explanatory variables showed that climate (temperature) and altitude play a relevant role in the definition of floristic identity in the areas studied. Moreover, chronic disturbances (cattle) may influence the definition of the species ecological strategies.

\section{Acknowledgements}

To Fundo de Apoio à Manutenção e ao Desenvolvimento da Educação Superior de Santa Catarina (FUMDES) for granting a scholarship to Manoela Bez Vefago. To Conselho Nacional de Desenvolvimento Científico e Tecnológico ( $\mathrm{CNPq}$ ) for granting a research productivity scholarship to Ana Carolina da Silva (Grant No. 309461/2014-6) and Pedro Higuchi (Grant No. 309617/2016-2). The authors also acknowledge the financial support provided by CNPq (441396/2017-8).

\section{Authors' Contributions}

Conceptualization: Vefago, M.B.; Silva, A.C.; Higuchi, P. Data acquisition: Vefago, M.B.; Silva, A.C.; Higuchi, P.; Santos, G.N.; Nunes, A.S.; Rodrigues Junior, C.; Lima, C.L.; Gross, A.; Kilca, R.V. Data analysis: Vefago, M.B.; Higuchi, P. Design of Methodology: Vefago, M.B.; Silva, A.C.; Higuchi, P. Writing and editing: Vefago, M.B.; Silva, A.C.; Higuchi, P.; Santos, G.N.; Nunes, A.S.; Rodrigues Junior, C.; Lima, C.L.; Gross, A.; Kilca, R.V.

\section{References}

Angiosperm Phylogeny Group. 2016. An update of the Angiosperm Phylogeny Group classification for the orders and families of flowering plants: APG IV. Botanical Journal of the Linnean Society 181: 1-20.

Benjamini, Y.; Hochberg, Y. 1995. Controlling the false discovery rate: a practical and powerful approach to multiple testing. Journal of the Royal Statistical Society. Series B (Methodological) 57: 289-300.

Brokaw, N.V.L. 1985. Gap-phase regeneration in a tropical forest. Ecology 66: 682-687.

Brokaw, N.V.L. 1987. Gap-phase regeneration of three pioneer tree species in a tropical forest. The Journal of Ecology 75: 9-19.

Dalla Rosa, A.; Silva, A.C.; Higuchi, P.; Marcon, A.K.; Missio, F.F.; Bento, M.A.; Silva, J.O.; Gonçalves, D.A.; Rodrigues Júnior, L.C. 2016. Natural regeneration of tree species in a cloud forest in Santa Catarina, Brazil. Revista Árvore 40: 1073-1082.

Denslow, J.S. 1987. Tropical rainforest gaps and tree species diversity. Annual Review of Ecology and Systematics 18: 431-451. 
Dray, S.; Dufour, A.B. 2007. The ade4 package: implementing the duality diagram for ecologists. Journal of Statistical Software 22: 1-20.

Dray, S.; Legendre, P. 2008. Testing the species traits-environment relationships: the fourth-corner problem revisited. Ecology 89: 3400-3412.

Dray, S.; Choler, P.; Dolédec, S.; Peres-Neto, P.R.; Thuiller, W.; Pavoine, S.; Ter Braak, C.J. 2014. Combining the fourthcorner and the RLQ methods for assessing trait responses to environmental variation. Ecology 95: 14-21.

Guidini, A.L.; Silva, A.C.; Higuchi, P.; Dalla Rosa, A.; Spiazzi, F.R.; Negrini, M.; Ferreira, T.S.; Salami, B.; Marcon, A.K.; Buzzi-Junior, F. 2014. Invasion by exotic tree species in forest remnants in "Planalto Sul Catarinense" region. Revista Árvore 38: 469-478 (in Portuguese, with abstract in English).

Higuchi, P.; Silva, A.C.; Ferreira, T.S.; Souza, S.T.; Gomes, J.P.; Silva, K.M.; Santos, K.F. 2012. Floristic composition and phytogeography of the tree component of Araucaria forest fragments in southern Brazil. Brazilian Journal of Botany 35: 145-157.

Higuchi, P.; Silva, A.C.; Buzzi-Junior, F.; Negrini, M.; Ferreira, T.S.; Souza, S.T.; Santos, K.F.; Vefago, M.B. 2015. Determinant factors on natural regeneration in a fragment of araucaria forest on Santa Catarina State plateau. Scientia Forestalis 43: 251-259 (in Portuguese, with abstract in English).

Hijmans, R.J.; Cameron, S.E.; Parra, J.L.; Jones, P.G.; Jarvis, A. 2005. Very high resolution interpolated climate surfaces for global land areas. International Journal of Climatology 25: 1965-1978.

Hijmans, R.J. 2017. Raster: geographic data analysis and modeling. R package. Available at: http://CRAN.R-project.org/ package $=$ raster $[$ Accessed Apr 3, 2017]

Inman-Narahari, F.; Ostertag, R.; Asner, G.P.; Cordell, S.; Hubbell, S.P.; Sack, L. 2014. Trade-offs in seedling growth and survival within and across tropical forest microhabitats. Ecology and Evolution 4: 3755-3767.

Janicke, J. 2008. Ecological effects caused by the grazing of cattle on public lands. The Honors Journal 13: 76-82.

Korning, J.; Balslev, H. 1994. Growth and mortality of trees in Amazonian tropical rain forest in Ecuador. Journal of Vegetation Science 4: 77-86.

Lieberman, D.; Lieberman, M.; Peralta, R.; Hartshorn, G.S. 1985. Mortality patterns and stand turnover rates in a wet tropical forest in Costa Rica. Journal of Ecology 73: 915924.

Liebsch, D.; Marques, M.C.M.; Goldenberg, R. 2008. How long does the Atlantic rain forest take to recover after a disturbance? Changes in species composition and ecological features during secondary succession. Biological Conservation 141: 1717-1725.

Lusk, C.H.; Jorgensen, M.A.; Bellingham, P.J. 2015. A coniferangiosperm divergence in the growth vs. shade tolerance trade-off underlies the dynamics of a New Zealand warmtemperate rain forest. Journal of Ecology 103: 479-488.

Machado, E.L.M.; Oliveira-Filho, A.T. 2010. Spatial patterns of tree community dynamics are detectable in a small (4 ha) and disturbed fragment of the Brazilian Atlantic forest. Acta Botanica Brasilica 24: 250-261.
Naimi, B. 2017. Usdm: uncertainty analysis for species distribution models. R package. Available at: http://CRAN.Rproject.org/package $=$ usdm [Accessed Apr 3, 2017]

Norden, N.; Chazdon, R.L.; Jiang, Y.H.; Vilchez-Alvarado, B. 2009. Resilience of tropical rain forests: tree community reassembly in secondary forests. Ecology Letters 12: 385394.

Oksanen, J.; Guillaume Blanchet, F.; Kindt, R.; Legendre, P.; Minchin, P.R.; O'Hara, R.B.; Simpson, G.L.; Solymos, P.; Stevens, M.H.H.; Wagner, H. 2017. Vegan: Community ecology package. $\mathrm{R}$ package. Available at: http://CRAN.Rproject.org/package $=$ vegan $[$ Accessed Apr 3, 2017]

Oliveira-Filho, A.T.; Carvalho, D.A.; Vilela, E.A.; Curi, N.; Fontes, M.A.L. 2004. Diversity and structure of the tree community of a fragment of tropical secondary forest of the brazilian Atlantic forest domain 15 and 40 years after logging. Brazilian Journal of Botany 27: 685-701.

Paludo, G.F.; Mantovani, A.; Reis, M.S. 2011. Regeneration in a natural population of Araucaria angustifolia (Araucariaceae). Revista Árvore 35: 1107-1119 (in Portuguese, with abstract in English).

Philipson, C.D.; Dent, D.H.; O'Brien, M.J.; Chamagne, J.; Dzulkifli, D.; Nilus, R.; Philips, S.; Reynolds, G.; Saner, P.; Hector, A. 2014. A trait-based trade-off between growth and mortality: evidence from 15 tropical tree species using sizespecific relative growth rates. Ecology and Evolution 4: 36753688.

Poorter, L. 2007. Are species adapted to their regeneration niche, adult niche, or both? The American Naturalist 169: 433-442.

Primack, R.B.; Ashton, P.S.; Chai, P.; Lee, H.S. 1985. Growth rates and population structure of Moraceae trees in Sarawak, east Malaysia. Ecology 66: 577-588.

Sheil, D.; May, R.M. 1996. Mortality and recruitment rate evaluations in heterogeneous tropical forests. Journal of Ecology 84: 91-100.

Silva, J.O.; Silva, A.C.; Higuchi, P.; Mafra, A.L.; Loebens, R.; Rodrigues-Junior, L.C.; Dalla Rosa, A.; Rech, C.C.C.; BuzziJunior, F. 2016. Environmental heterogeneity and natural regeneration in an alluvial mixed araucaria forest. Scientia Forestalis 44: 787-797 (in Portuguese, with abstract in English).

Silva, J.O.; Silva, A.C.; Higuchi, P.; Mafra, A.L.; Goncalves, D.A.; Buzzi-Junior, F.; Dalla Rosa, A.; Cruz, A.P.; Ferreira, T.S. 2017. Floristic composition and phytogeography contextualization of the natural regeneration of an alluvial forest located in the "Planalto Sul Catarinense" region, SC, Brazil. Revista Árvore 41: e410203.

Smale, M.C.; Dodd, M.B.; Burns, B.R.; Power, I.L. 2008. Longterm impacts of grazing on indigenous forest remnants on North Island hill country, New Zealand. New Zealand Journal of Ecology 32: 57-66.

Souza, A.F. 2007. Ecological interpretation of multiple population size structures in trees: the case of Araucaria angustifolia in South America. Austral Ecology 32: 524-533.

Souza, A.F.; Cortez, L.S.R.; Longhi, S.J. 2012. Native forest management in subtropical South America: long-term effects of logging and multiple-use on forest structure and diversity. Biodiversity and Conservation 21: 1953-1969. 
Souza, C.C.; Higuchi, P.; Silva, A.C.; Souza, K.; Dalla Rosa, A.; Rech, C.C.C.; Rodrigues-Junior, L.C.R.; Walter, F.F. 2017. Floristic-structural variation of natural regeneration along different topographic positions of an ecotonal forest in Santa Catarina, Brazil. Revista Árvore 41: e410305.

Stern, M.; Quesada, M.; Stoner, K.E. 2002. Changes in composition and structure of a tropical dry forest following intermittent cattle grazing. Revista de Biologia Tropical 50: 1021-1034.

Swaine, M.D.; Whitmore, T.C. 1988. On the definition of ecological species groups in tropical rain forest. Vegetatio 75 : 81-86.

Tabarelli, M.; Peres, C.A.; Melo, F.P.L. 2012. The 'few winners and many losers' paradigm revisited: emerging prospects for tropical forest biodiversity. Biological Conservation 155: 136140.

Ter Braak, C.J.; Cormont, A.; Dray, S. 2012. Improved testing of species traits-environment relationships in the fourth corner problem. Ecology 93: 1525-1526.

Tobler, M.W.; Cochard, R.; Edwards, P.J. 2003. The impact of cattle ranching on large-scale vegetation patterns in a coastal savanna in Tanzania. Journal of Applied Ecology 40: 430-444.

Toriola, D.; Chareyre, P.; Buttler, A. 1998. Distribution of a primary forest plant species in a $18^{\circ}$ year old secondary forest in French Guiana. Journal of Tropical Ecology 14: 323-340.
Vibrans, A.C.; Sevegnani, L.; Uhlmann, A.; Schorn, L.A.; Sobral, M.G.; Gasper, A.L.; Lingner, D.V.; Brogni, E.; Klemz, G.; Godoy, M.B.; Verdi, M. 2011. Structure of mixed ombrophyllous forests with Araucaria angustifolia (Araucariaceae) under external stress in southern Brazil. Revista de Biologia Tropical 59: 1371-1387.

Vicente-Silva, J.; Bergamin, R.S.; Zanini, K.J.; Pillar, V.D.; Müller, S.C. 2016. Assembly patterns and functional diversity of tree species in a successional gradient of Araucaria forest in southern Brazil. Natureza \& Conservação 14: 67-73.

Whitmore, T.C. 1984. Tropical Rain Forest of the Far East. Clarendon Press, Oxford, England.

Whitmore, T.C. 1990. An Introduction to Tropical Rain Forest. Clarendon Press, Oxford, England.

Wright, S.J.; Kitajima, K.; Kraft, N.J.B.; Reich, P.B.; Wright, I.J.; Bunker, D.E.; Condit, R.; Dalling, J.W.; Davies, S.J.; Díaz, S.; Engelbrecht, B.M.J.; Harms, K.E.; Hubbell, S.P.; Marks, C.O.; Ruiz-Jaen, M.C.; Salvador, C.M.; Zanne, A.E. 2010. Functional traits and the growth-mortality trade-off in tropical trees. Ecology 91: 3664-3674. 